\title{
Evaluation of the Effect of Biofield Energy Treatment on Physicochemical and Thermal Properties of Hydroxypropyl $\beta$-Cyclodextrin
}

Keywords: Hydroxypropyl $\beta$-Cyclodextrin; The Trivedi Effect ${ }^{\circledR}$; Energy Healing Treatment; Complementary and Alternative Medicine; PXRD: PSA; DSC; TGA/DTG

\begin{abstract}
Hydroxypropyl $\beta$-Cyclodextrin (HPBCD) has many applications in the foods, nutraceuticals, and pharmaceuticals industries. The primary objective of this study was to evaluate the influence of the Trived Effect $^{\circledR}$ on the physicochemical and thermal properties of HPBCD using modern analytical techniques. The HPBCD test sample was divided into two parts. One part did not receive the Biofield Energy Treatment and was called as a control sample, whereas, the other part received the Biofield Energy Treatment remotely by a renowned Biofield Energy Healer, Alice Branton and was called as a treated sample. The particle size values of the treated HPBCD were decreased by $5.32 \%, 1.51 \%$, $0.36 \%$, and $1.12 \%$ at $d_{10^{\prime}} d_{50^{\prime}} d_{90^{\prime}}$ and $D(4,3)$, respectively compared with the control sample. Thus, the surface area of the treated HPBCD was significantly increased by $6.67 \%$ compared with the control sample. The evaporation and melting temperature of the treated HPBCD were increased by $4.76 \%$ and $1.92 \%$, respectively compared with the control sample. However, the latent heat of evaporation and latent heat of fusion of the treated HPBCD were significantly decreased by $7.95 \%$ and $33.85 \%$, respectively compared to the control sample. The total weight loss in the treated HPBCD sample was decreased by $1.83 \%$ compared with the control sample. But, the residue amount was $40.55 \%$ more in the case of the treated HPBCD compared to the control sample. The Trivedi Effect ${ }^{\circledR}$-Consciousness Energy Healing Treatment introduced new form of HPBCD which may show better stability, solubility, dissolution rate, absorption, and bioavailability compared to the control sample. The treated would be more useful for the improvement of solubility of the lipophilic drug, stabilize volatile and unstable compounds, preparation of cholesterol free food products, weight loss supplements, and other anti-obesity medication, and also for the industry using it as a raw material.
\end{abstract}

\section{Introduction}

Hydroxypropyl $\beta$-cyclodextrin (HPBCD) is the cycloamylose with 7-membered sugar ring molecule in the structure. Cyclodextrins are hydrophilic outside and hydrophobic inside; they can form complexes with hydrophobic (lipophilic) compounds. The unique structures of cyclodextrin owe their stability to intramolecular hydrogen bonding between the hydroxyl groups of neighbouring glucopyranose units. Therefore they can improve the solubility, bioavailability and membrane permeability of such compounds $[1,2]$. In the food, pharmaceutical, and nutraceutical industries, HPBCD is also employed for the preparation of cholesterol-free products, alcohol powder, weight loss supplements, aerosols, and other antiobesity medications. Mainly due to its surface-active properties, $\mathrm{HPBCD}$ can also be used as an emulsifying fiber [3-6]. It can stabilize

\section{Journal of}

Pharmaceutics \& Pharmacology

\author{
Branton $\mathrm{A}^{1}$, Trivedi $\mathrm{MK}^{1}$, Trivedi $\mathrm{D}^{1}$, Nayak $\mathbf{G}^{1}$ and \\ Jana $\mathbf{S}^{2^{\star}}$ \\ Trivedi Global Inc., Henderson, USA \\ ${ }^{2}$ Trivedi Science Research Laboratory Pvt. Ltd., Bhopal, India
}

Address for Correspondence

Snehasis Jana, Trivedi Science Research Laboratory Pvt. Ltd., Bhopal, India. Tel: +91-022-25811234; Email: publication@trivedieffect.com

Submission: 04 October 2018

Accepted: 08 November 2018

Published: 13 November 2018

Copyright: (C) 2018 Branton A, et al. This is an open access article distributed under the Creative Commons Attribution License, which permits unrestricted use, distribution, and reproduction in any medium, provided the original work is properly cited.

volatile or unstable compounds, reduce the unwanted tastes and odor, intensify color, improve light stability and increase water solubility [3,7]. HPBCD used to produce chiral HPLC columns for the chiral enantiomers separation, and are also the core ingredient in air freshener (i.e., Febreze) which "trap" odor, thereby reduce the odor $[2,8]$. The solubility of natural cyclodextrins is very poor; even the chemically modified cyclodextrins can only achieve a 50\% (w/v) concentration in water [1].

The Trivedi Effect ${ }^{\circledR}$ (Biofield Energy Healing Treatment) has the significant impact on the physicochemical properties (particle size, surface area, crystallite size, solubility, thermal properties, etc.) of the various objects [9-11]. The Trivedi Effect is natural and only scientifically proven phenomenon in which a person can harness this inherently intelligent energy from the Universe and transmit it anywhere on the planet through the possible mediation of neutrinos [12]. A unique para-dimensional electromagnetic field exists around the body of every living organism, which generated from the uninterrupted movement of the electrically charged particles (ions, cells, etc.) inside the body known as the "Biofield" (A Putative Energy Field). All over the world the Biofield based Energy Healing Therapies have been accepted and reported in many scientific journals with significant outcomes against various disease conditions $[13,14]$. The National Institutes of Health (NIH) and National Center for Complementary and Alternative Medicine (NCCAM) recommend and included the Energy therapy under the Complementary and Alternative Medicine (CAM) category along with naturopathy, homeopathy, traditional Chinese herbs and medicines, Ayurvedic medicine, Tai Chi, Qi Gong, Reiki, healing touch, chiropractic/ osteopathic manipulation, etc., which has been accepted by the most of the U.S. population $[15,16]$. The Trivedi Effect $^{\circledR}$ Consciousness Energy Healing Treatment (Biofield Energy Healing Treatment) also reported their significant outcomes in the different field of sciences which are Biotechnology [17,18], Microbiology [19,20], Agriculture [21,22], Material Science [23,24], Organic Chemistry [25,26], Nutraceutical/Pharmaceutical Sciences [27-29], and medical science $[30,31]$. Therefore, the current study was designed to evaluate the influence of the Trivedi Effect ${ }^{\oplus}$ Consciousness Energy Healing 
Citation: Branton A, Trivedi MK, Trivedi D, Nayak G, Jana S. Evaluation of the Effect of Biofield Energy Treatment on Physicochemical and Thermal Properties of Hydroxypropyl $\beta$-Cyclodextrin. J Pharmaceu Pharmacol. 2018; 6(1): 5.
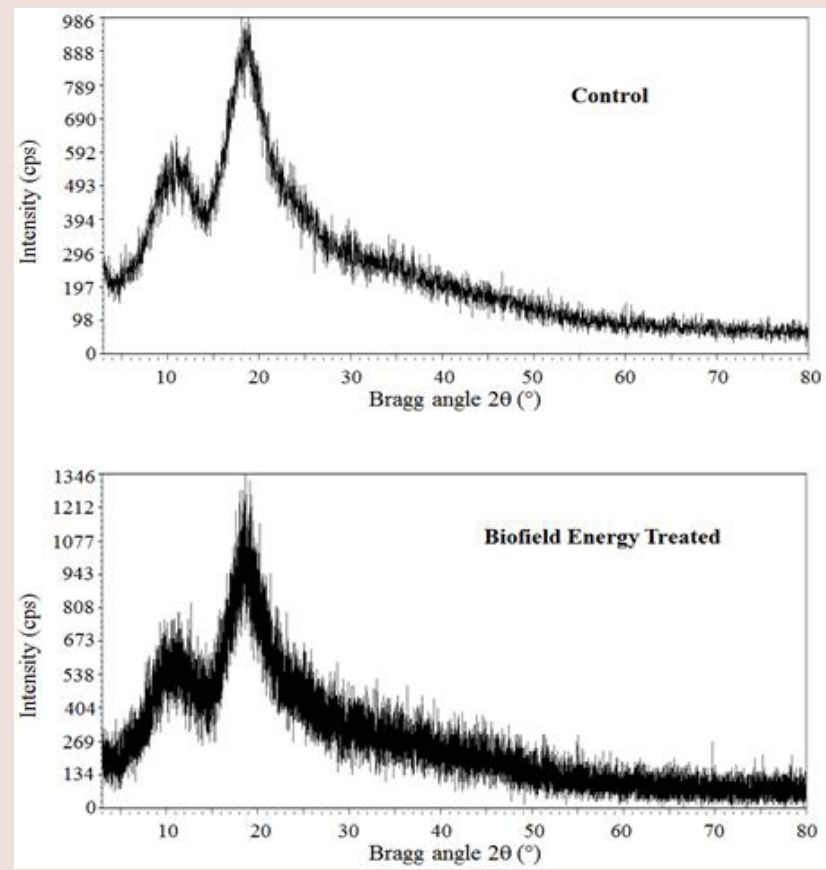

Figure 1: PXRD diffractograms of the control and the Biofield Energy Treated hydroxypropyl $\beta$-cyclodextrin.

Table 1: Particle size distribution of the control and the Biofield Energy Treated hydroxypropyl $\beta$-cyclodextrin.

\begin{tabular}{|c|c|c|c|c|c|}
\hline Parameter & $\mathbf{d}_{10}(\boldsymbol{\mu m})$ & $\mathbf{d}_{\mathbf{5 0}}(\boldsymbol{\mu m})$ & $\mathbf{d}_{\mathbf{9 0}}(\boldsymbol{\mu m})$ & $\mathbf{D}(\mathbf{4 , 3})(\boldsymbol{\mu m})$ & $\mathbf{S S A}\left(\mathbf{m}^{2} / \mathbf{g}\right)$ \\
\hline Control & 23.1 & 77.72 & 163.02 & 86.47 & 0.15 \\
\hline Biofield Treated & 21.87 & 76.55 & 162.44 & 85.5 & 0.16 \\
\hline Percent change $^{*}(\%)$ & -5.32 & -1.51 & -0.36 & -1.12 & 6.67 \\
\hline
\end{tabular}

Table 2: DSC data for both control and the Biofield Energy Treated samples of hydroxypropyl $\beta$-cyclodextrin.

\begin{tabular}{|c|c|c|c|c|}
\hline \multirow{2}{*}{ Sample } & \multicolumn{2}{|c|}{ Melting point $\left.\mathbf{(}^{\circ} \mathbf{C}\right)$} & \multicolumn{2}{c|}{$\Delta \mathbf{H}(\mathbf{J} / \mathbf{g})$} \\
\cline { 2 - 5 } & $\mathbf{1}^{\text {st }}$ Peak & $\mathbf{2}^{\text {nd }}$ Peak & Evaporation & Melting \\
\hline Control Sample & 110.02 & 317.25 & 115.7 & 35.6 \\
\hline Biofield Energy Treated & 115.26 & 323.35 & 106.5 & 23.55 \\
\hline \% Change & 4.76 & 1.92 & -7.95 & -33.85 \\
\hline
\end{tabular}

Treatment on HPBCD using Powder X-ray Diffraction (PXRD), Particle Size Analysis (PSA), Differential Scanning Calorimetry (DSC) analytical techniques, and Thermo Gravimetric Analysis (TGA)/Differential Thermo Gravimetric Analysis (DTG).

\section{Materials and Methods}

\section{Chemicals and reagents}

The hydroxypropyl $\beta$-cyclodextrin (HPBCD) powder was purchased from Tokyo Chemical Industry Co. Ltd, Japan. Remaining chemicals used during the experiments were of analytical grade available in India.

\section{Consciousness energy healing treatment strategies}

The test sample (i.e., HPBCD) powder was divided into two parts. One part of the test sample was received the Trivedi Effect ${ }^{\circ}$ Consciousness Energy Healing Treatment remotely under standard laboratory conditions for 3 minutes and known as the Biofield Energy Treated HPBCD sample. The Biofield Treatment was provided through the healer's unique energy transmission process by the renowned Biofield Energy Healer, Alice Branton, USA, to the HPBCD sample. Subsequently, the other part of the test sample was considered as a control/untreated sample (Biofield Energy Treatment was not provided). The control sample was later treated with a "sham" healer. The "sham" healers did not have any understanding about the Biofield Energy Treatment. After the treatment, the Biofield Energy Treated and untreated HPBCD samples were kept in sealed conditions and characterized using modern analytical techniques.

\section{Characterization}

The PXRD, PSA, DSC, and TGA analysis of HPBCD were performed. The PXRD analysis of HPBCD powder sample was performed with the help of Rigaku MiniFlex-II Desktop X-ray diffractometer (Japan) [32,33]. The average size of crystallites was calculated from PXRD data using the Scherrer's equation (1)

$$
\mathrm{G}=\mathrm{k} \lambda / \beta \cos \theta
$$

Where $\mathrm{G}$ is the crystallite size in $\mathrm{nm}, \mathrm{k}$ is the equipment constant (0.94), $\lambda$ is the radiation wavelength $(0.154056 \mathrm{~nm}$ for $\mathrm{K} \alpha 1$ emission), $\beta$ is the full-width at half maximum, and $\theta$ is the Bragg angle [34].

Similarly, the PSA (particle sizes and surface area) was performed using Malvern Mastersizer 2000, from the UK with a detection range between $0.01 \mu \mathrm{m}$ to $3000 \mu \mathrm{m}$ using the wet method. The DSC analysis of HPBCD was performed with the help of DSC Q200, TA instruments. The TGA/DTG thermograms of HPBCD were obtained with the help of TGA Q50 TA instruments [35,36].

The $\%$ change in particle size, specific surface area (SSA), peak intensity, crystallite size, melting point, latent heat, weight loss and the maximum thermal degradation temperature $\left(\mathrm{T}_{\max }\right)$ of the Biofield Energy Treated sample was calculated compared with the control sample using the following equation 2 :

$$
\% \text { change }=\frac{[\text { Treated-Control }]}{\text { Control }} \mathrm{X} 100
$$

\section{Results and Discussion}

\section{Powder X-ray diffraction (PXRD) analysis}

PXRD study of the control and the Biofield Energy Treated HPBCD was done to determine the crystalline pattern of the samples. The PXRD experimental results of the control and the Biofield Energy Treated HPBCD samples did not show sharp and intense peaks in the respective diffractograms (Figure 1). Thus, it was concluded that both samples were amorphous in nature and the Biofield Energy Treatment might not affect the crystallinity and pattern of the HPBCD.

\section{Particle size analysis (PSA)}

The PSA analysis of both the control and the Biofield Energy Treated HPBCD were performed, and the results are presented in (Table 1). The particle size values of the control sample at $d_{10}, d_{50}$, $\mathrm{d}_{90}$, and $\mathrm{D}(4,3)$ were $23.10 \mu \mathrm{m}, 77.72 \mu \mathrm{m}, 163.02 \mu \mathrm{m}$, and 86.47 $\mu \mathrm{m}$, respectively. Similarly, the particle sizes of the Biofield Energy Treated HPBCD at $d_{10}, d_{50}, d_{90}$, and D (4,3) were $21.87 \mu \mathrm{m}, 76.55$ 
Citation: Branton A, Trivedi MK, Trivedi D, Nayak G, Jana S. Evaluation of the Effect of Biofield Energy Treatment on Physicochemical and Thermal Properties of Hydroxypropyl $\beta$-Cyclodextrin. J Pharmaceu Pharmacol. 2018; 6(1): 5.
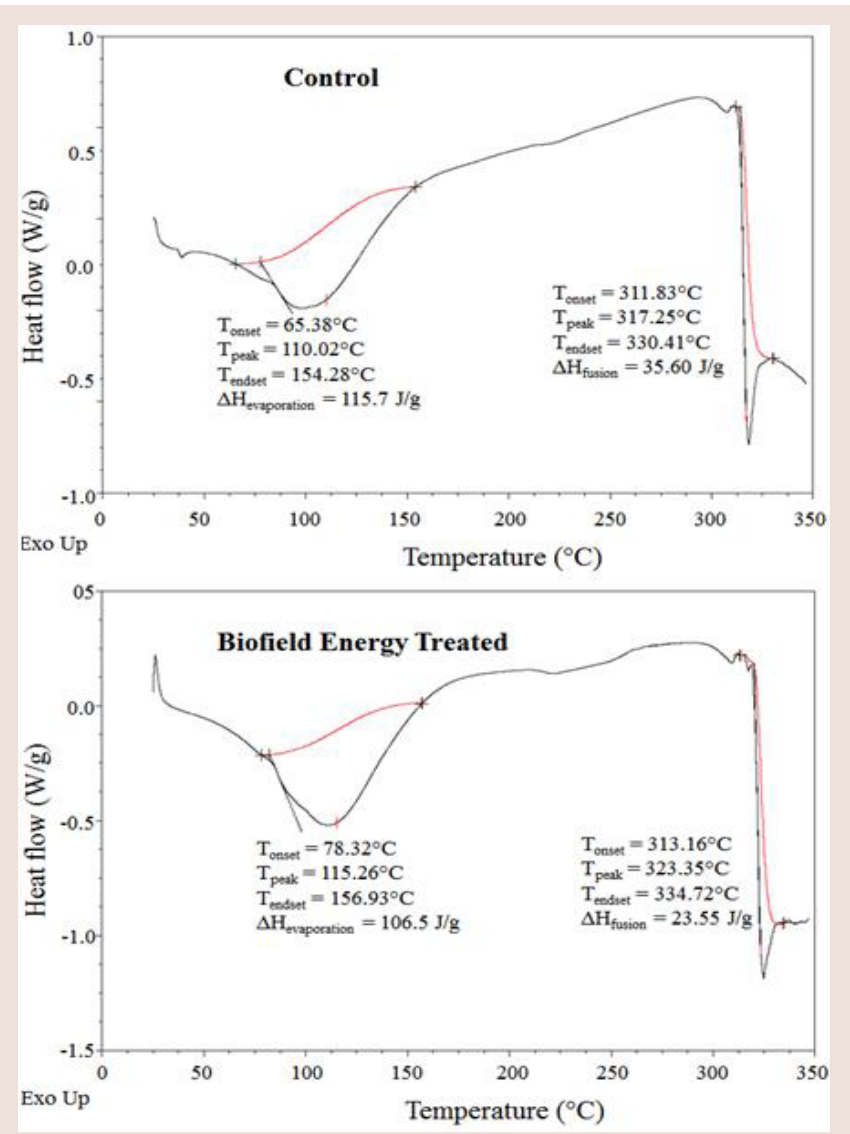

Figure 2: DSC thermograms of the control and the Biofield Energy Treated hydroxypropyl $\beta$-cyclodextrin.

$\mu \mathrm{m}, 162.44 \mu \mathrm{m}$, and $85.5 \mu \mathrm{m}$, respectively. Therefore, the particle size values in the Biofield Energy Treated HPBCD was decreased by $5.32 \%, 1.51 \%, 0.36 \%$, and $1.12 \%$ at $\mathrm{d}_{10}, \mathrm{~d}_{50}, \mathrm{~d}_{90}$, and $\mathrm{D}(4,3)$, respectively compared to the control sample (Table 1 ). The specific surface area of the Biofield Energy Treated HPBCD $\left(0.16 \mathrm{~m}^{2} / \mathrm{g}\right)$ was increased by $6.67 \%$ compared with the control sample $\left(0.15 \mathrm{~m}^{2} / \mathrm{g}\right)$. Hence, the Consciousness Energy Healing Treatment might act as an external force to breakdown the larger HPBCD particles to the smaller particle, hence increased the surface area. The particle size, shape, and surface area of a particle havethe significant impact on the solubility, dissolution rate, absorption, bioavailability, and even the therapeutic efficacy if it is a drug [37-39]. Literally, the solubility of HPBCD is $50 \%(\mathrm{w} / \mathrm{v})$ concentration in water [1]. Due to reduced particle size and increased surface area, the surface-active properties of the Biofield Energy Treated HPBCD would be very high. The improved quality of the Biofield Energy Treated HPBCD would be more useful for the improvement of solubility of the lipophilic drug, stabilize volatile and unstable compounds, preparation of cholesterol free food products, weight loss supplements and other anti-obesity medication [3-7] and for the industry using it as a raw material.

\section{Differential scanning calorimetry (DSC) analysis}

The thermal analysis of both control and the Biofield Energy Treated samples has been performed to evaluate the impact of the Trivedi Effect ${ }^{\circ}$ on the thermal behavior of HPBCD. The thermograms of the control HPBCD sample showed two sharp endothermic peaks at $110.02{ }^{\circ} \mathrm{C}$ and $317.25^{\circ} \mathrm{C}$ (Figure 2). Similarly, the thermograms of the Biofield Energy Treated HPBCD sample showed the sharp endothermic peaks at $115.26{ }^{\circ} \mathrm{C}$ and $323.35{ }^{\circ} \mathrm{C}$ (Figure 2). The $1^{\text {st }}$ endothermic peak was due to the evaporation of water molecule from the sample, whereas the $2^{\text {nd }}$ large endothermic pick was due to the melting of HPBCD. The experimental results were well correlated with the reported literature [40]. The evaporation and melting temperature of the Biofield Energy Treated HPBCD were increased by $4.76 \%$ and $1.92 \%$, respectively compared with the control sample (Table 2). However, the latent heat of evaporation $\left(\Delta \mathrm{H}_{\text {evaporation }}\right)$ and latent heat of fusion $\left(\Delta \mathrm{H}_{\text {fusion }}\right)$ of the Biofield Energy Treated HPBCD were significantly decreased by $7.95 \%$ and $33.85 \%$, respectively compared with the control sample (Table 2). Although the heat energy required by the Biofield Energy Treated HPBCD was less, but the evaporation and melting point was increased compared to the control sample. Therefore, it was concluded that the thermal stability of the Biofield Energy Treated HPBCD was increased compared to the control sample. Any change in the molecular chains and the crystal structure influence the latent heat of fusion [41]. Therefore, Alice Branton's Biofield Energy Treatment could have disturbed the molecular chains and crystal structure of HPBCD which lead to the elevation of the melting point of the treated sample compared to the control sample.

Thermal gravimetric analysis (TGA)/ differential thermogravimetric analysis (DTG)

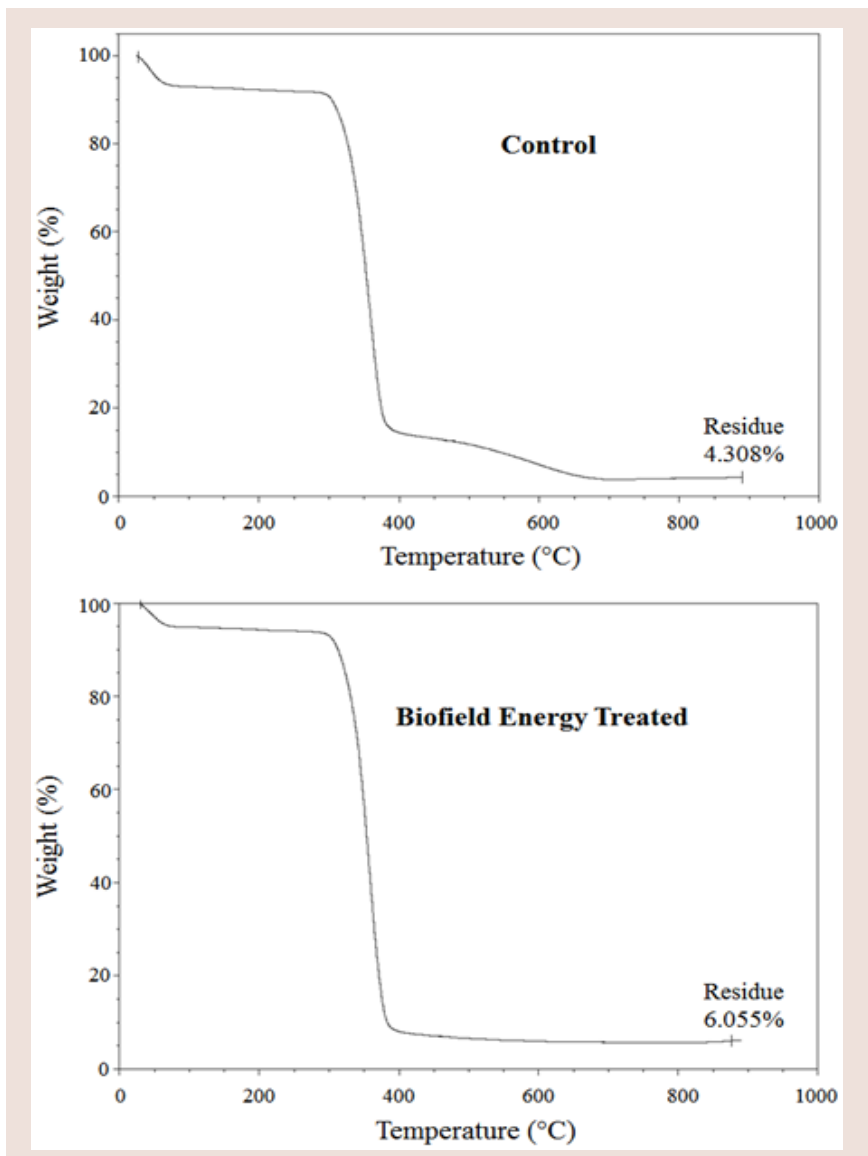

Figure 3: TGA thermograms of the control and the Biofield Energy Treated hydroxypropyl $\beta$-cyclodextrin. 
Citation: Branton A, Trivedi MK, Trivedi D, Nayak G, Jana S. Evaluation of the Effect of Biofield Energy Treatment on Physicochemical and Thermal Properties of Hydroxypropyl $\beta$-Cyclodextrin. J Pharmaceu Pharmacol. 2018; 6(1): 5.

Table 3: TGA/DTG data of the control and Biofield Energy Treated samples of hydroxypropyl $\beta$-cyclodextrin.

\begin{tabular}{|c|c|c|c|}
\hline \multirow{2}{*}{ Sample } & \multicolumn{2}{|c|}{ TGA } & DTG \\
\cline { 2 - 4 } & Total weight loss (\%) & Residue \% & T $_{\max }\left({ }^{\circ} \mathbf{C}\right)$ \\
\hline Control & 95.69 & 4.31 & 357.49 \\
\hline Biofield Energy Treated & 93.95 & 6.06 & 357.23 \\
\hline \% Change* & -1.83 & 40.55 & -0.07 \\
\hline
\end{tabular}

"denotes the percentage change of the Biofield Energy Treated sample with respect to the control sample,

$\mathrm{T}_{\max }=$ the temperature at which maximum weight loss takes place in $\mathrm{TG}$ or peak temperature in DTG.

The TGA/DTG thermal analysis was performed, and the thermograms of the control and the Biofield Energy Treated HPBCD samples are displayed in (Figures 3 and 4). The thermograms showed two steps of the degradation process. The total weight loss in the Biofield Energy Treated HPBCD (93.95\%) was decreased by $1.83 \%$ compared with the control sample (95.69\%). Therefore, the residue amount was $40.55 \%$ more in the Biofield Energy Treated HPBCD compared to the control sample (Table 3).

Similarly, the DTG thermograms of the control and the Biofield Energy Treated HPBCD showed one peak (Figure 4). The Maximum Thermal Degradation Temperature $\left(\mathrm{T}_{\max }\right)$ of the Biofield Energy Treated HPBCD were almost the same compared with the control sample. Overall, TGA/DTG thermal analysis revealed that the thermal stability of the Biofield Energy Treated HPBCD was increased compared with the control sample.

\section{Conclusion}

The Trivedi Effect ${ }^{\oplus}$ Consciousness Energy Healing Treatment has shown a significant impact on the particle size, surface area, and thermal properties of hydroxypropyl $\beta$-cyclodextrin. The particle size values of the Biofield Energy Treated HPBCD were decreased compared to the control sample. The specific surface area of the Biofield Energy Treated HPBCD was significantly increased by $6.67 \%$ compared with the control sample. Due to reduced particle size and increased surface area, the surface-active properties of the Biofield Energy Treated HPBCD would be very high. The evaporation and melting temperature of the Biofield Energy Treated HPBCD were increased compared with the control sample. However, the $\Delta \mathrm{H}_{\text {evaporation }}$ and $\Delta \mathrm{H}_{\text {fusion }}$ of the Biofield Energy Treated HPBCD were significantly decreased by $7.95 \%$ and $33.85 \%$, respectively compared with the control sample. The total weight loss in the Biofield Energy Treated sample was decreased compared with the control sample. However, the residue amount was $40.55 \%$ more in case of the Biofield Energy Treated HPBCD compared to the control sample. It can be concluded that the Trivedi Effect ${ }^{\bullet}$ Consciousness Energy Healing Treatment introduced a new polymorphic form of HPBCD which may show better stability, solubility, dissolution rate, absorption, and bioavailability. This quality would be more useful for the improvement of solubility of the lipophilic drug, stabilize volatile and unstable compounds, preparation of cholesterol free food products, weight loss supplements, and other anti-obesity medication and also for the industry using it as a raw material.

\section{References}

1. Gould S, Scott RC (2005) 2-Hydroxypropyl- $\beta$-cyclodextrin (HP- $\beta-C D$ ): A toxicology review. Food Chem Toxicol 43: 1451-1459.

2. Morrison PWJ, Connon CJ, Khutoryanskiy VV (2013) Cyclodextrin-mediated enhancement of riboflavin solubility and corneal permeability. Mol Pharm 10:
756-762.

3. Rosseels ML, Delaunois AG, Hanon E, Guillaume PJ, Martin FD, et al. (2013) Hydroxypropyl- $\beta$-cyclodextrin impacts renal and systemic hemodynamics in the anesthetized dog. Regul Toxicol Pharmacol 67: 351-359.

4. Artiss JD, Brogan K, Brucal M, Moghaddam M, Jen KL (2006) The effects of a new soluble dietary fiber on weight gain and selected blood parameters in rats. Metabolism 55: 195-202.

5. Grunberger G, Jen KL, Artiss JD (2007) The benefits of early intervention in obese diabetic patients with FBCx: A new dietary fibre. Diabetes Metab Res Rev 23: 56-62.

6. Bouchal F, Skiba M, Chaffai N, Hallouard F, Fatmi S, et al. (2015) Fast dissolving cyclodextrin complex of piroxicam in solid dispersion Part I: Influence of $\beta-C D$ and $H P \beta-C D$ on the dissolution rate of piroxicam. Int $J$ Pharm 478: 625-632.

7. Marcolino VA, Zanin GM, Durrant LR, Benassi Mde T, Matioli G (2011) Interaction of curcumin and bixin with $\beta$-cyclodextrin: Complexation methods, stability, and applications in food. J Agric Food Chem 59: 3348-3357.

8. Motoyama A, Suzuki A, Shirota O, Namba R (2002) Direct determination of pindolol enantiomers in human serum by column-switching LC-MS/MS using a phenylcarbamate- $\beta$-cyclodextrin chiral column. J Pharm Biomed Anal 28: 97-106.

9. Dabhade VV, Tallapragada RMR, Trivedi MK (2009) Effect of external energy on the atomic, crystalline, and powder characteristics of antimony and bismuth powders. Bull Mater Sci 32: 471-479.

10. Trivedi MK, Branton A, Trivedi D, Nayak G, Gangwar M, et al. (2015) Effect of biofield energy treatment on chlorophyll content, pathological study, and molecular analysis of cashew plant (Anacardium occidentale L.). J Plant Sci 3: $372-382$

11. Trivedi MK, Branton A, Trivedi D, Shettigar H, Nayak G, et al. (2015) Assessment of antibiogram of multidrug-resistant isolates of enterobacter aerogenes after biofield energy treatment. J Pharma Care Health Sys 2: 145.

12. Trivedi MK, Mohan TRR (2016) Biofield energy signals, energy transmission and neutrinos. Am J Modern Phys 5: 172-176.

13. Rubik B, Muehsam D, Hammerschlag R, Jain S (2015) Biofield science and healing: history, terminology, and concepts. Glob Adv Health Med 4: 8-14.

14. Oschman LJ (2003) Energy medicine in therapeutics and human performance. Philadelphia: Butterworth Heinemann 1-12.

15. Barnes PM, Bloom B, Nahin RL (2008) Complementary and alternative medicine use among adults and children: United States, 2007. Natl Health Stat Report 12: 1-23.

16. Koithan M (2009) Introducing complementary and alternative therapies. J Nurse Pract 5: 18-20.

17. Trivedi MK, Branton A, Trivedi D, Nayak G, Mondal SC, et al. (2015) Evaluation of plant growth regulator, immunity and DNA fingerprinting of biofield energy treated mustard seeds (Brassica juncea). Agric Forestry Fisheries. 4: 269-274

18. Trivedi MK, Branton A, Trivedi D, Nayak G, Mondal SC, et al. (2015) Morphological characterization, quality, yield and DNA fingerprinting of biofield energy treated alphonso mango (Mangifera indica L.) J Food Nutr Sci 3: 245-250.

19. Trivedi MK, Branton A, Trivedi D, Shettigar H, Nayak G, et al. (2015) Antibiogram, biochemical reactions and genotyping characterization of biofield treated Staphylococcus aureus. Am J Bio Sci 3: 212-220.

20. Trivedi MK, Branton A, Trivedi D, Nayak G, Mondal SC, et al. (2015) Antimicrobial sensitivity, biochemical characteristics and biotyping of Staphylococcus saprophyticus: An impact of biofield energy treatment. J Women's Health Care 4: 271.

21. Trivedi MK, Branton A, Trivedi D, Nayak G, Gangwar M, et al. (2015) Agronomic characteristics, growth analysis, and yield response of biofield treated mustard, cowpea, horse gram, and groundnuts. Int J Genet Genom 3: $74-80$. 
Citation: Branton A, Trivedi MK, Trivedi D, Nayak G, Jana S. Evaluation of the Effect of Biofield Energy Treatment on Physicochemical and Thermal Properties of Hydroxypropyl $\beta$-Cyclodextrin. J Pharmaceu Pharmacol. 2018; 6(1): 5.

22. Trivedi MK, Branton A, Trivedi D, Nayak G, Mondal SC, et al. (2015) Evaluation of plant growth, yield and yield attributes of biofield energy treated Mustard (Brassica juncea) and Chick pea (Cicer arietinum) Seeds. Agric Foresty Fisheries 4: 291-295.

23. Trivedi MK, Patil S, Tallapragada RM (2013) Effect of bio field treatment on the physical and thermal characteristics of vanadium pentoxide powders. $J$ Mater Sci Eng S 11:001.

24. Trivedi MK, Mohan R, Branton A, Trivedi D, Nayak G, et al. (2015) Evaluation of atomic, physical, and thermal properties of bismuth oxide powder: An impact of biofield energy treatment. Am J Nano Res Appl 3: 94-98.

25. Trivedi MK, Branton A, Trivedi D, Nayak G, Panda P, et al. (2016) Evaluation of the isotopic abundance ratio in biofield energy treated resorcinol using gas chromatography-mass spectrometry technique. Pharm Anal Acta 7: 481

26. Trivedi MK, Branton A, Trivedi D, Nayak G, Panda P, et al. (2016) Gas chromatography-mass spectrometric analysis of isotopic abundance of ${ }^{13} \mathrm{C},{ }^{2} \mathrm{H}$, and ${ }^{18} \mathrm{O}$ in biofield energy treated $\mathrm{p}$-Tertiary Butylphenol (PTBP). American Journal of Chemical Engineering 4: 78-86.

27. Trivedi MK, Branton A, Trivedi D, Nayak G, Lee AC, et al. (2017) A comprehensive analytical evaluation of the Trivedi Effect ${ }^{\circledR}$ - Energy of Consciousness Healing Treatment on the physical, structural, and thermal properties of zinc chloride. Am J Appl Chem 5: 7-18.

28. Trivedi MK, Branton A, Trivedi D, Nayak G, Plikerd WD, et al. (2017) A systematic study of the biofield energy healing treatment on physicochemical, thermal, structural, and behavioral properties of magnesium gluconate. Int $\mathrm{J}$ Bioorgan Chem 2: 135-145.

29. Trivedi MK, Branton A, Trivedi D, Shettigar H, Bairwa K, et al. (2015) Fourier transform infrared and ultraviolet-visible spectroscopic characterization of biofield treated salicylic acid and sparfloxacin. Nat Prod Chem Res 3: 186.

30. Trivedi MK, Patil S, Shettigar H, Mondal SC, Jana S (2015) The potential impact of biofield treatment on human brain tumor cells: A time-lapse video microscopy. J Integr Oncol 4: 141.
31. Trivedi MK, Patil S, Shettigar H, Gangwar M, Jana S (2015) In vitro evaluation of biofield treatment on cancer biomarkers involved in endometrial and prostate cancer cell lines. J Cancer Sci Ther 7: 253-257.

32. (1997) Desktop X-ray Diffractometer "MiniFlex+". The Rigaku Journal 14: 2936.

33. Zhang T, Paluch K, Scalabrino G, Frankish N, Healy AM, et al. (2015) Molecular structure studies of (1S,2S)-2-benzyl-2,3-dihydro-2-(1Hinden-2yl)-1H-inden-1-ol. J Mol Struct 1083: 286-299.

34. Langford JI, Wilson AJC (1978) Scherrer after sixty years: A survey and some new results in the determination of crystallite size. J Appl Cryst 11: 102-113.

35. Trivedi MK, Sethi KK, Panda P, Jana S (2017) A comprehensive physicochemical, thermal, and spectroscopic characterization of zinc (II) chloride using X-ray diffraction, particle size distribution, differential scanning calorimetry, thermogravimetric analysis/differential thermogravimetric analysis, ultraviolet-visible, and Fourier transform-infrared spectroscopy. Int J Pharm Investig 7: 33-40.

36. Trivedi MK, Sethi KK, Panda P, Jana S (2017) Physicochemical, thermal and spectroscopic characterization of sodium selenate using XRD, PSD, DSC, TGA/DTG, UV-vis, and FT-IR. Marmara Pharm J 21/2: 311-318.

37. Chereson R (2009) Bioavailability, bioequivalence, and drug selection. In: Makoid CM, Vuchetich PJ, Banakar UV (eds) Basic pharmacokinetics (1 ${ }^{\text {st }}$ ed) Pharmaceutical Press, London.

38. Khadka P, Ro J, Kim H, Kim I, Kim JT, et al. (2014) Pharmaceutical particle technologies: An approach to improve drug solubility, dissolution and bioavailability. Asian J Pharm Sci 9: 304-316.

39. Buckton G, Beezer AE (1992) The relationship between particle size and solubility. Int J Pharmaceutics 82: R7-R10.

40. Moriwaki C, Costa GL, Ferracini CN, de Moraes FF, Zanin GM, et al. (2008) Enhancement of solubility of Albendazole by complexation with $\beta$-cyclodextrin. Braz J Chem Eng Vol 25: 255-267.

41. Zhao Z, Xie M, Li Y, Chen A, Li G, et al. (2015) Formation of curcumin nanoparticles via solution-enhanced dispersion by supercritical $\mathrm{CO}_{2}$. Int $\mathrm{J}$ Nanomedicine 10: 3171-3181.

\section{Acknowledgements}

The authors are grateful to Central Leather Research Institute, SIPRA Lab. Ltd., Trivedi Science, Trivedi Global, Inc., Trivedi Testimonials, and Trivedi Master Wellness for their assistance and support during this work 